\title{
Obituary
}

\section{FRANK REITH (11 June 1972-14 October 2019) The man with the gold bug}

\author{
Allan Pring ${ }^{1}$, Joël Brugger ${ }^{2 *}$ (D) and Jeremiah Shuster ${ }^{3,4}$ \\ ${ }^{1}$ College of Science and Engineering, Flinders University, Bedford Park, SA 5042, Australia; ${ }^{2}$ School of Earth, Atmosphere and the Environment, Monash University, \\ Clayton, VIC 3800, Australia; ${ }^{3} \mathrm{~S}$ chool of Biological Sciences, The University of Adelaide, Adelaide, SA 5005, Australia; and ${ }^{4} \mathrm{CSIRO}$ Land and Water, Contaminant \\ Chemistry and Ecotoxicology, PMB2, Glen Osmond, SA 5064, Australia
}

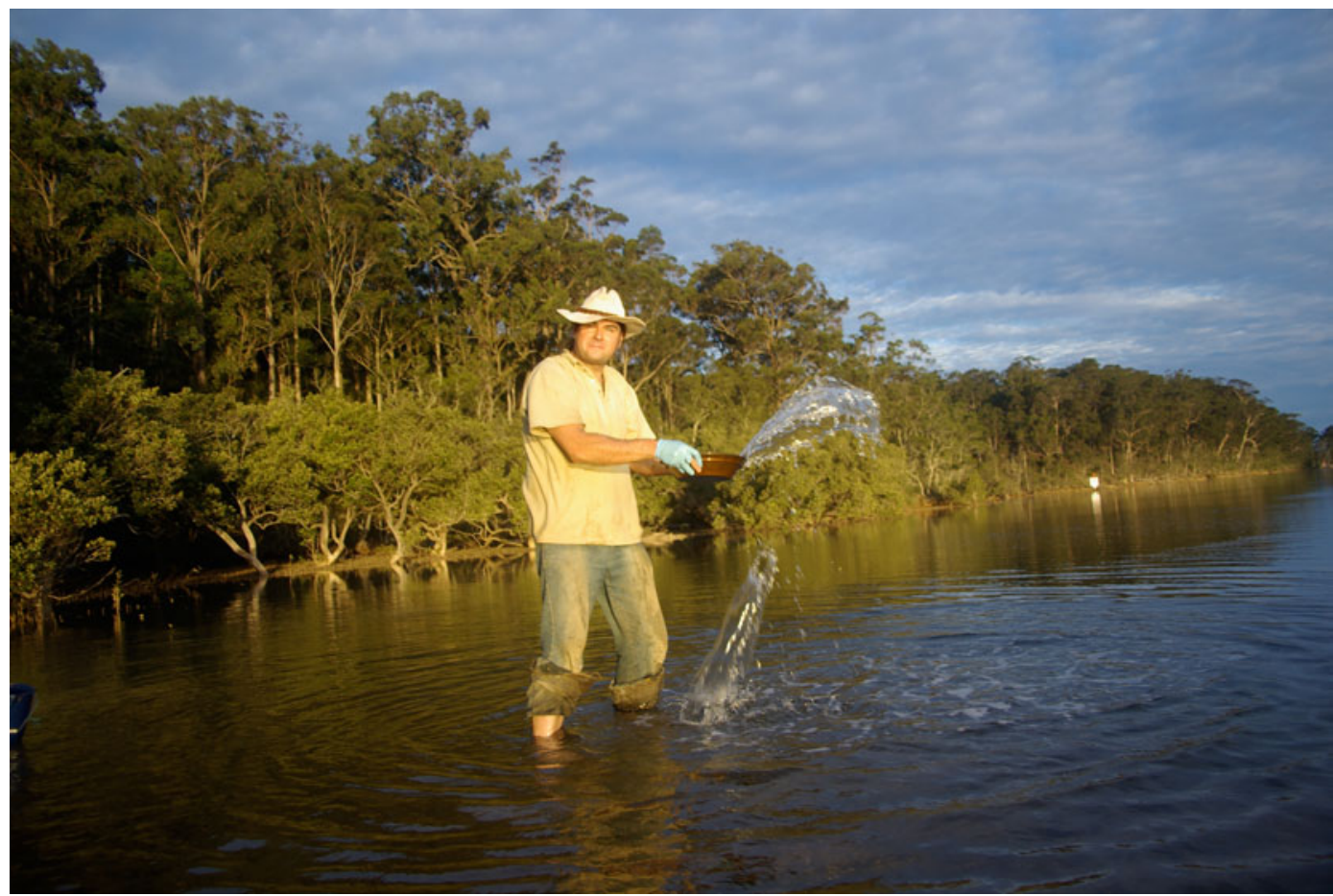

Fig. 1. Frank Reith demonstrating gold panning near the historic Tomakin Park gold mine, New South Wales, Australia (photo 28/3/2007; Reith et al., 2005, 2006).

Frank Reith's research legacy (Fig. 1) is the discovery that bacteria make a 'home' on gold grains and these microorganisms render gold mobile in the surrounding environment - belying the yellow metal's reputation for inertness and resistance to corrosion (Fig. 2). Frank was the first to integrate molecular characterisation with the 'classic' geochemical and morphological characterisation of placer gold grains, a radical step-change from the geological literature. His interdisciplinary approach to research integrated the latest cutting-edge techniques in chemical, spectroscopic, molecular and proteomic analysis. Frank had the gift of exciting people, of all walks of life, about his research. Throughout his career, he loved collaborative research and developed a vast and

\footnotetext{
${ }^{*}$ Author for correspondence: Joël Brugger, Email: joel.brugger@monash.edu Cite this article: Pring A., Brugger J. and Shuster J. (2021) FRANK REITH (11 June 1972-14 October 2019) The man with the gold bug. Mineralogical Magazine 85, 3-11. https://doi.org/10.1180/mgm.2020.41
}

diverse network of interdisciplinary collaborators (friends) across the globe. Although his academic career was relatively short, Frank published $>75$ scientific papers, listed in the Appendix. To the broader geoscience community, Frank was a world-leading geomicrobiologist, fascinated by gold and devoted to delineating the interactions between bacteria and precious metals. He described himself more simply as, "the man with the gold bug".

\section{The man}

Frank Reith, the elder of two children, was born on the 11th of June 1972 to Elke and Ernst-Wolfgang Reith, a family of wine makers in the Rhine-Hesse region, Germany. Frank grew up in the town of Woerrstadt and attended High School in Nieder-Olm. After fulfilling his civil service obligations as an ambulance driver, he attended the University of Bayreuth and graduated in 1999 with a Master's Degree in Ecological 
Fig. 2. Frank's approach to precious metal microbiology. (a) Obtaining fresh samples under field sterile conditions means dropping the lab coat (gloves are required, though) and turning to the mining methods used by small scale miners and prospectors since times immemorial (Grosses Wasser river, Gondo, Switzerland; 8/8/2014; from front to back, Frank, Emilie Delpech, Barbara Etschmann and Tina Reith). (b) The gold and PGE grains are prepared carefully on-site to preserve DNA and/or delicate surface biofilms at their surface (Kilkivan, Queensland). (c) The surface of a washed alluvial gold grain from Kilkivan shows a typical bacteriomorph feature; do such features indicate biological cycling of gold? (d) Frank discovered that fresh, carefully prepared, alluvial gold samples are often covered by extensive biofilms, as in this example from Lively's Gold Find, Flinders Ranges, South Australia. Genetic analyses revealed that the microbial communities on the gold grains differ from those of the surrounding sediments and include a number of metallophiles. (e) The biofilms also commonly contain nanoparticulate $\mathrm{Au}$ particles, indicating that the biofilms contribute to the cycling of gold in the near surface by transforming 'solid gold' into mobile and reactive gold nanoparticles. Frank demonstrated that this happens in many different environments over four continents - highlighting similarities and well as the uniqueness of each environment (gold grain from the beach placer at Orepuki, New Zealand; Reith et al., 2012b). (f) The identification of the microbial cycling occurring on the surface of natural gold grains inspired a diverse experimental program. Illustrated here is an SEM image of the results of column experiments spiked with soluble gold and selected organisms that were identified on the surface of natural gold grains. The coloured SEM image highlights the association between bacterial cells at the surface of quartz grains, secondary gold particles via a network of nanowires (Fairbrother et al., 2013).
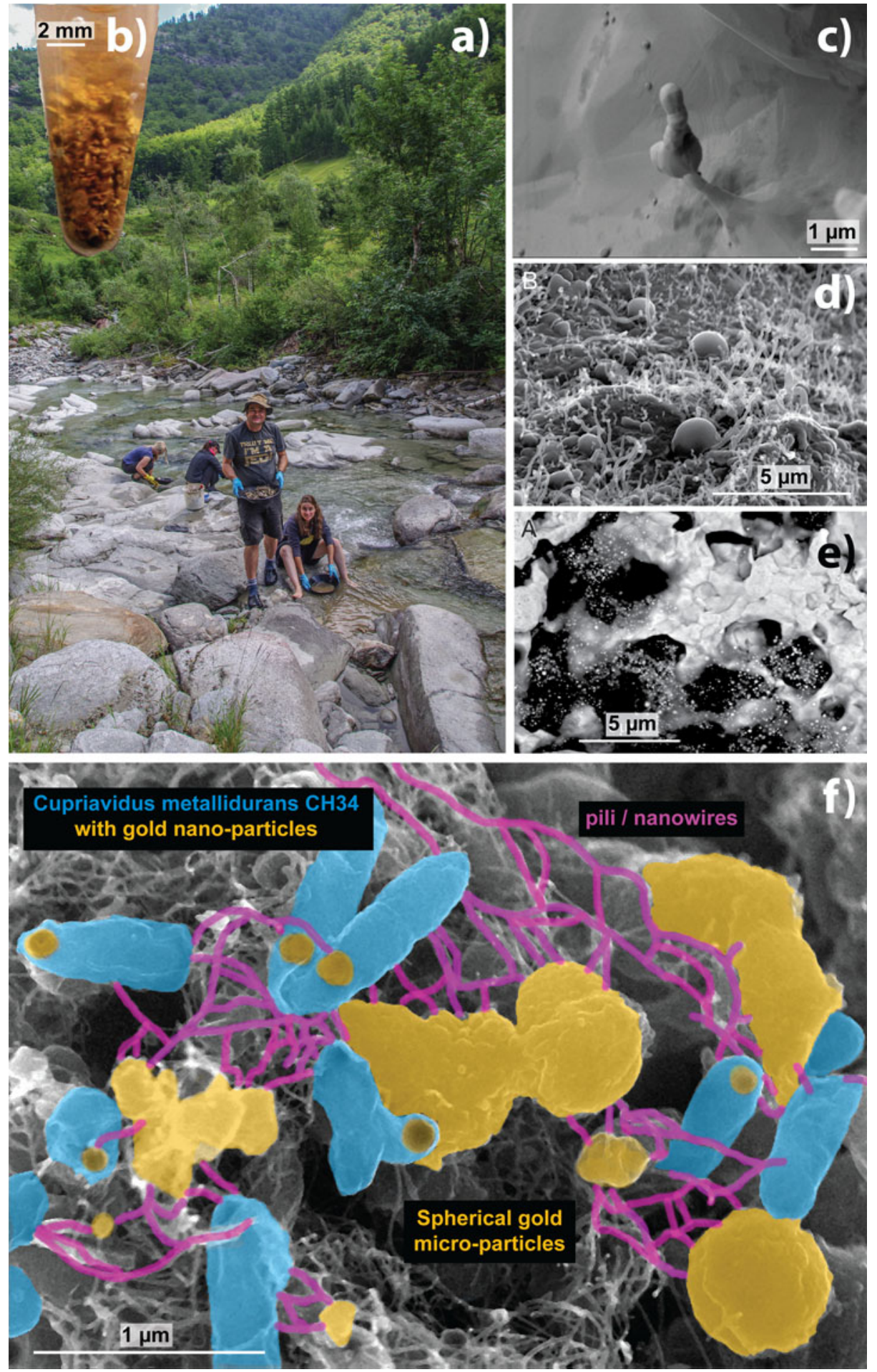

Microbiology and Geo-ecology as well as a degree in Marketing and Economics. As an avid The Lord of the Rings enthusiast, and an adventurer at heart, Frank then backpacked across the USA, Canada and Australia. Captivated by Australia's diverse landscapes, spectacular coastlines, and colourful history of gold mining, he chose to do his doctorate thesis, The Microbiology of Gold, at the Australian National University in Canberra under the supervision of Professor 'Bear' McPhail (Fig. 3).
Frank received his PhD in November of 2006 and his curiosity to discover more of the outback (and eventually the world) through field work and research never waned. Frank's journey continued when he moved to Adelaide, South Australia, to begin a postdoctoral position at the Commonwealth Scientific and Industrial Research Organization (CSIRO) on the Waite Campus. Having made a home in the scenic sea-side southern suburb of Marino, Frank enjoyed balancing research with sailing 

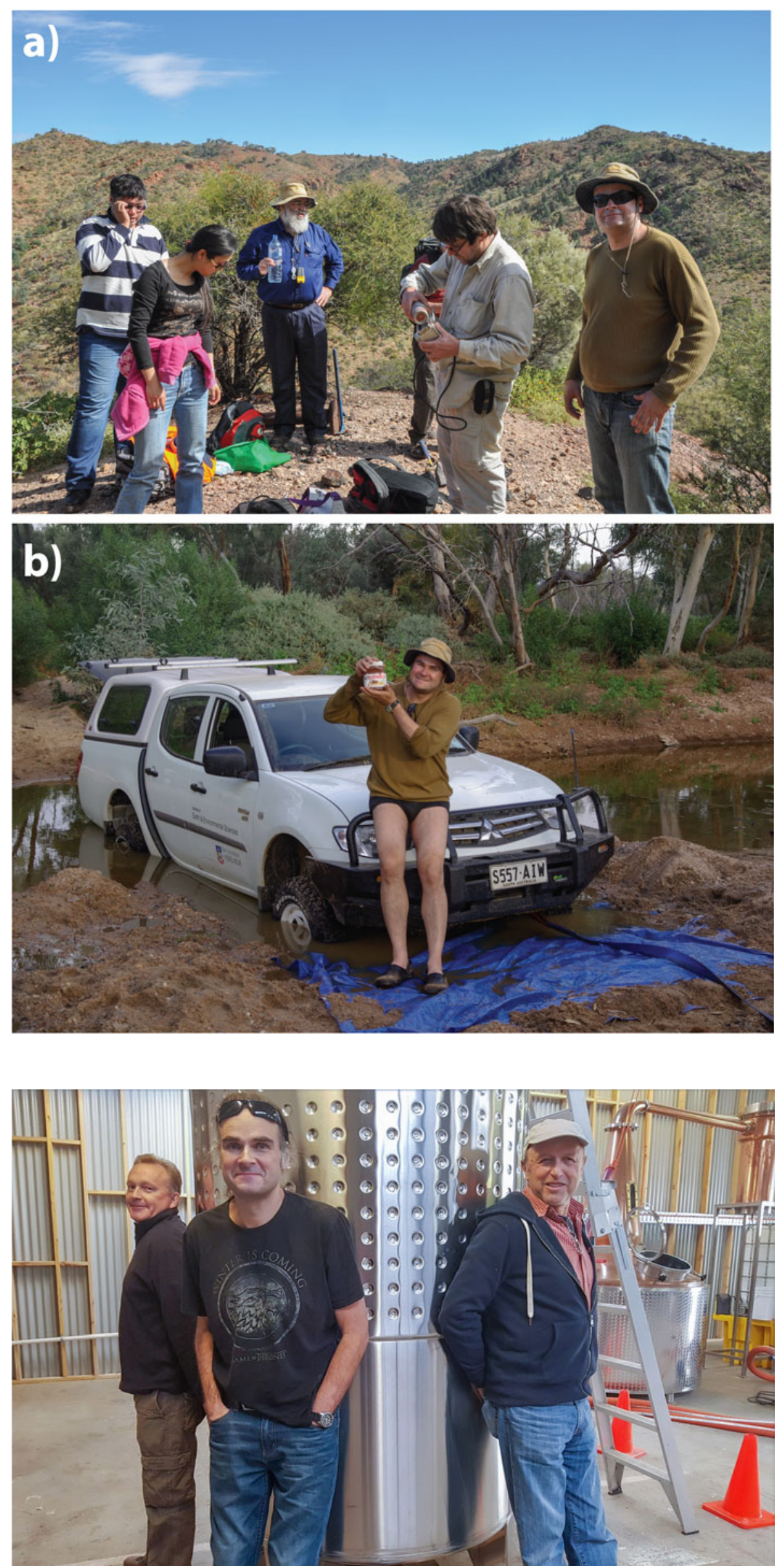

Fig. 3. Joint field trip with Frank's PhD supervisor, D.C. 'Bear' McPhail, to the Northern Flinders Ranges in May 2011. Bear never visited Frank in the field during his PhD (2003-2006) - this was their first and only joint field trip. (a) Reaching Radium Ridge, the site of early mining for radium from 1910 to the mid-1930s (photo 18/5/2011). From left to right, Fred (Bear's PhD student), Yuan Mei, Bear, Joël Brugger and Frank. (b) The trip became memorable when we discovered that rain and thixotropy combined to make a dry river bed an efficient trap for vehicles. Spending an unplanned night in the wilderness revealed that Frank was best prepared, as the only person (of seven participants) with a sleeping bag and a pillow (temperature dropped to $\sim 5^{\circ} \mathrm{C}$ ). On the next day, Frank is celebrating one of his favourite foods, Nutella, while waiting for the rescue party (21/5/ 2011). No situation is hopeless with Nutella!
Fig. 4. Good chemistry. Frank at Paul Shand's (on the left) Spirit of Gondwana whiskey distillery in the Adelaide Hills together with Andreas Schmidt Mumm (on the right) and his wife Tina (the photographer; photo $16 / 5 / 2018$ ) 


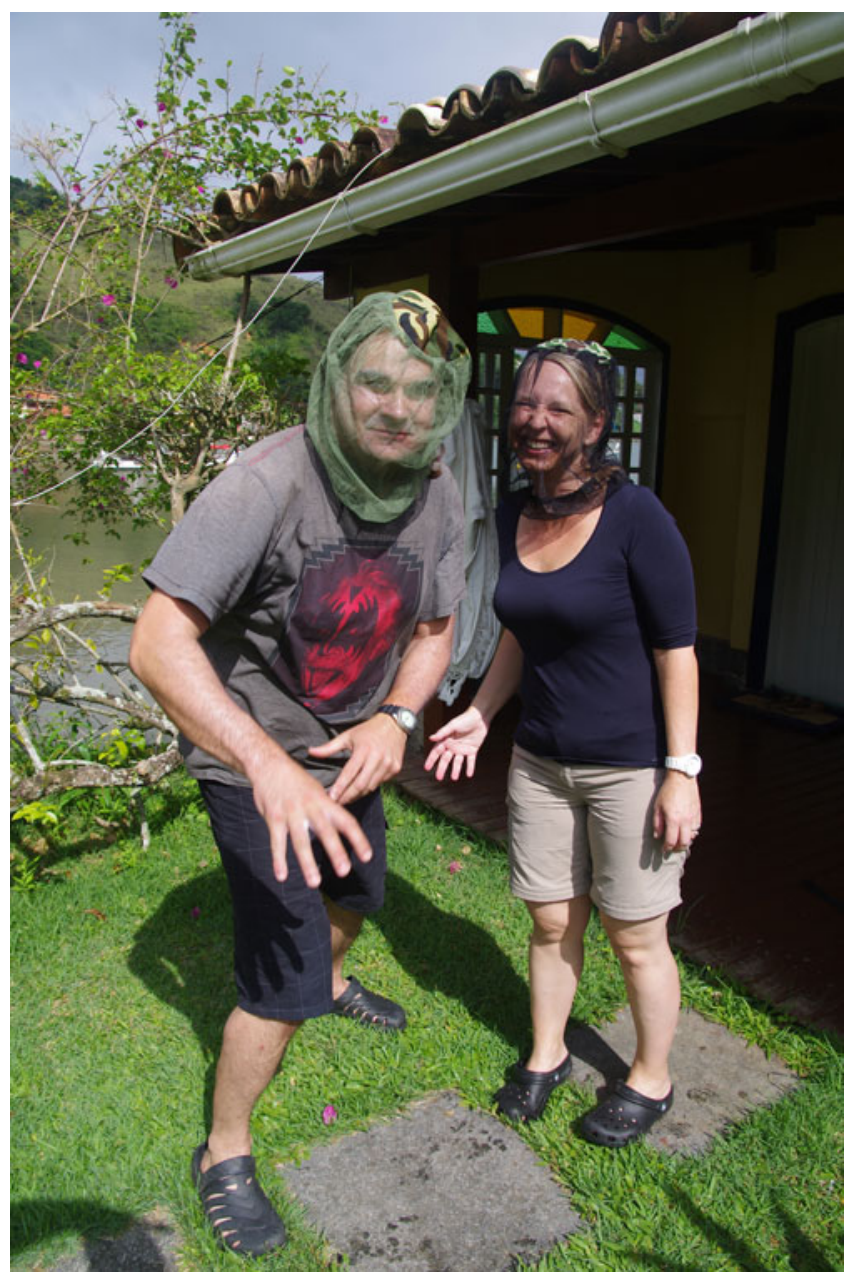

Fig. 5. Frank and Tina taking a pause in the chase for PGE grains. Angra dos Rei, Brazil, 10/12/2012.

and discovering epicurean delights in the Barossa Valley, Clare Valley and McLaren Vale. Indeed, wine appreciation was in his blood and he sought to visit every cellar door in South Australia, often bringing family and friends on wine-tasting adventures to his favourite places. Frank was also a dedicated whiskey enthusiast (Fig. 4).

Frank was an avid fan of Dr. Who - the ultimate adventurer. Much like this famous doctor, Frank discovered he worked and travelled best with a 'companion'. In 2010, Frank met his future wife, Tina Reitz, on a trip back to Germany. Tina, who was working as a social worker at the time, was seeking travel advice for a trip to Australia. With strong mutual attraction and a passion for travel, they soon became a long-distance couple. Two years later, Tina travelled to Australia and embarked on a ten week-long journey with Frank. They explored the East Coast up to the historic gold town of Gympie in Queensland before returning to Adelaide, which soon became the duo's home base. Tina became Frank's companion when they married on the 20th of September 2013 and together they lived happily, taking pleasure in walking the neighbour's dog, Oscar, along the beach near their home base. For the next 5 years, the duo planned Frank's extensive research-based travels to obtain 'fresh' samples of gold and other precious metals from around the world (Brazil, Finland, Sweden, Norway, Switzerland, Germany, France, UK, South
Africa, New Zealand, USA and Australia) to better understand bacteria-gold interactions. With their shared passion for photography, they documented each fieldtrip capturing the memories of shared experiences throughout their journey (Fig. 5).

\section{The gold bug}

Frank advocated that scientific research should be fun and novel discoveries come by embracing the challenge of uncertainty with friends (Fig. 3b). The need to obtain fresh gold samples - and grains of the much rarer Platinum Group Elements (PGE) - inspired many of Frank's adventures. Frank also loved driving, listening to a range of music (from Scottish bagpiping to heavy metal) and, in Australia, enjoyed hours of cricket on the radio. Many field trips became amazing road trips, logging tens of thousands of kilometres through Australia, Europe, Brazil and South Africa (Fig. 6). Frank was in his element during field work, and these trips were thrilling because they combined exciting scientific discoveries with an endless curiosity for nature and people alike. Careful and extensive planning ensured that these trips achieved their scientific goals.

In 2007, Frank was awarded a prestigious Australian Research Council (ARC) Postdoctoral Industrial Fellowship for his research project, 'Bacterial mechanisms of gold mobilisation and precipitation with applications to mineral processing and exploration'. Frank held this fellowship through the University of Adelaide (UA) but remained at CSIRO because he integrated comfortably into that campus. The positive outcomes of this project enabled Frank to develop as an early career researcher and build an independent research programme. As his fellowship came to a close, Frank applied for a highly competitive ARC Australian Research Fellowship in 2010. For this application, endorsement from the School of Earth and Environmental Sciences (UA) was required; however, it received tepid support. Thanks to well established collaborations at Flinders University, in the south of Adelaide, Frank's proposal received greater support and was awarded funding to explore interactions between platinum-group metals and bacteria. During this time, Frank formally joined the 'Minerals Microbes and Solution' group (formerly 'Minerals Metals and Solutions'), a consortium of researchers from the South Australian Museum and the University of Adelaide. With Frank's increasing grant success and a promising research profile, the University of Adelaide was anxious to retain his expertise. Frank relished in negotiating hard with UA authorities to not only move his fellowship to UA but to also provide him a continuing position with additional funding. During his fellowship, Frank led an ARC Linkage Project that involved the collaboration between UA, Newmont, Barrick Gold, the South Australian Museum, and a network of interdisciplinary colleagues across the globe. This collaboration successfully developed a live cell biosensor that could detect gold concentrations down to $1 \mathrm{ppb}$. While this applied research was not commercially viable for exploration, it did lead to a series of landmark papers.

In 2015, Frank was awarded a highly prestigious ARC Future Fellowship, one of only two fellowships granted to researchers based in South Australia that year. This fellowship enabled Frank to continue his research in gold geomicrobiology. In doing so, he recruited a postdoctoral fellow and another graduate student to join his research group, 'Microbes and Heavy Metal'. In addition to leading his own research programme, Frank also contributed to the Biome of Australia Soil Environments (BASE) project (Bissett et al., 2016). As part of his contribution, he led an epic $>10,000 \mathrm{~km}$ field trip starting in Adelaide, travelling across the continent to 

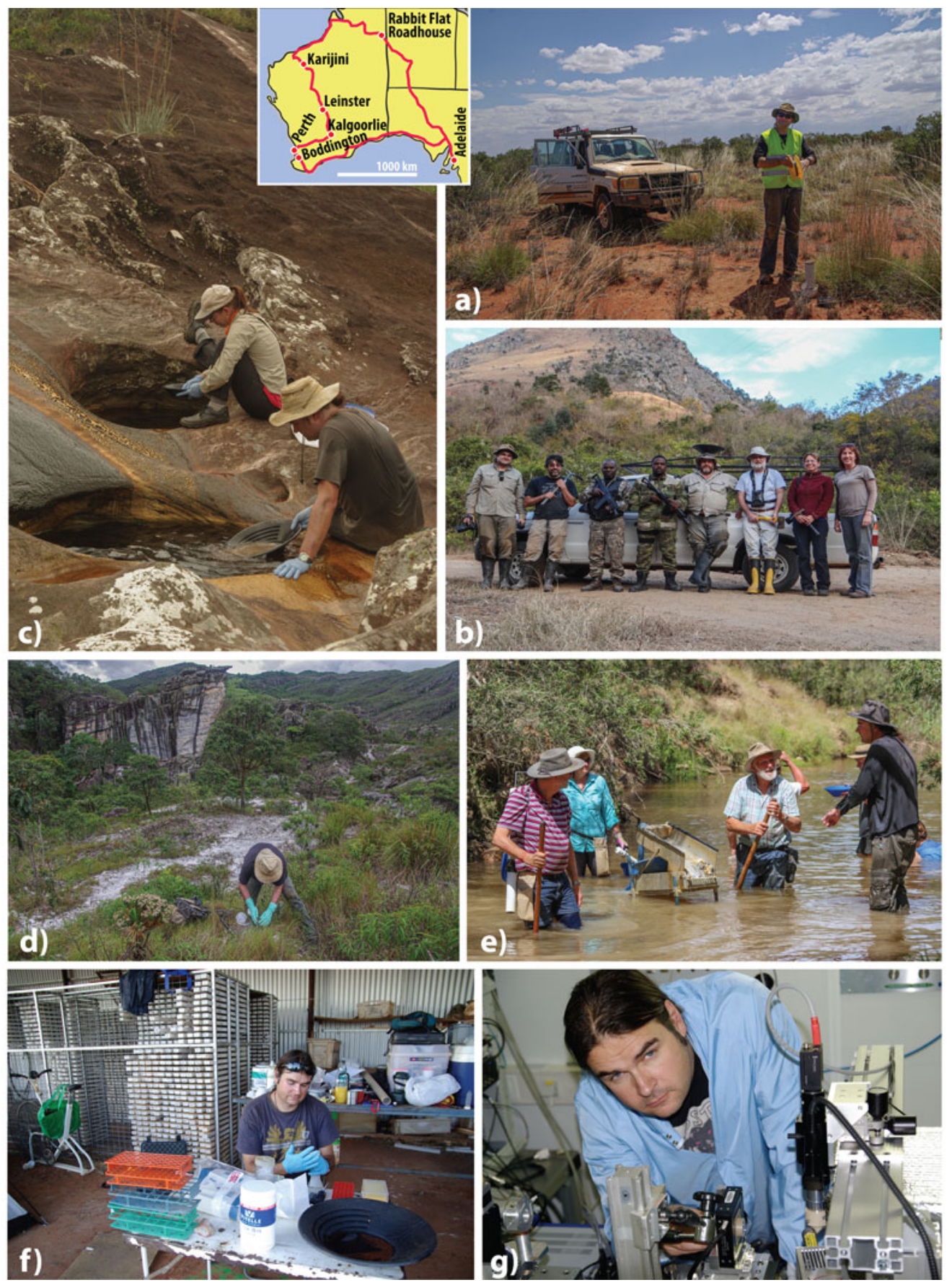

Fig. 6. Frank at work. (a) Despite the heat being Frank's greatest enemy in the field, he loved the beauty of the isolated wilderness. Sampling groundwater for Au content near the Rabbit Flat Roadhouse, Northern Territory, that claimed to be the most isolated roadhouse in Australia (photo 4/11/2011; Ta et al., 2014). The insert map shows the full extent of this $>10,000 \mathrm{~km}$ sampling trip; one soil sample was collected every $100 \mathrm{~km}$ to contribute to the biomes of Australian soil environments soil microbial diversity database (Bissett et al., 2016). (b) The team at Concession Creek, Agnes Mine, Barberton gold fields, South Africa (16/8/2016; Sanyal et al., 2020). This trip also delivered unexpected results. Several sites turned out to be heavily contaminated with mercury due to intense activity by illegal miners which led to a study of the effect of heavy metals on Au cycling (Sanyal et al., 2020). Some of the on-going illegal mining is conducted by rather unsavoury types, requiring a well-armed security escort. From left to right: Frank, Joël (Monash University), two security personnel from Agnes Mine, Jaco Delport and Roger Dixon (University of Pretoria), Barbara Etschmann (Monash University) and our local guide, Andrea Botha. (c,d) Deciphering the geobiochemistry of palladium, gold and other platinum-group minerals at the type locality for the mineral palladium, Corrego Bom Sucesso in Brazil (Reith et al., 2014; 2019); photo (c), panning for PGE, 25/11/2012; and photo $(d)$, sampling local soils, 29/11/2012. The remarkable dendritic Pt-Pd rich nuggets from this locality were attributed a biological origin early on, but fresh samples were required to prove this hypothesis by demonstrating the existence of specific organisms on the surface of these grains. There were some tense moments when our guide declared the trip to be a failure following the strenuous walk to the remote site: local Garimpeiros had not worked the claim in a while (one died of old age; one broke his hip; and one took a 'real' job), and academics could not possibly have the stamina, muscles and skills to extract the rare minerals from local sediments. Four days of hard work provided the material to prove the biological cycling of PGE in tropical sediments (Reith et al., 2014; 2019). (e) Sluicing at Eldorado gold fields near Wangaratta, Victoria, Australia (3/1/2018). $(f)$ Field laboratory at the Titania prospect near The Granites gold mine, Northern Territory (2/1/2008). Day-time temperatures well in excess of $40^{\circ} \mathrm{C}$ and high humidity made a 2008 expedition to the Tanami desert one of the toughest field trips in Frank's career (Reith et al., 2012a). (g) Frank changing a sample during a late-night shift at the ID22 beamline at the European Synchrotron Research Facility (ESRF), Grenoble, France (25/2/2008; Brugger et al., 2013). 

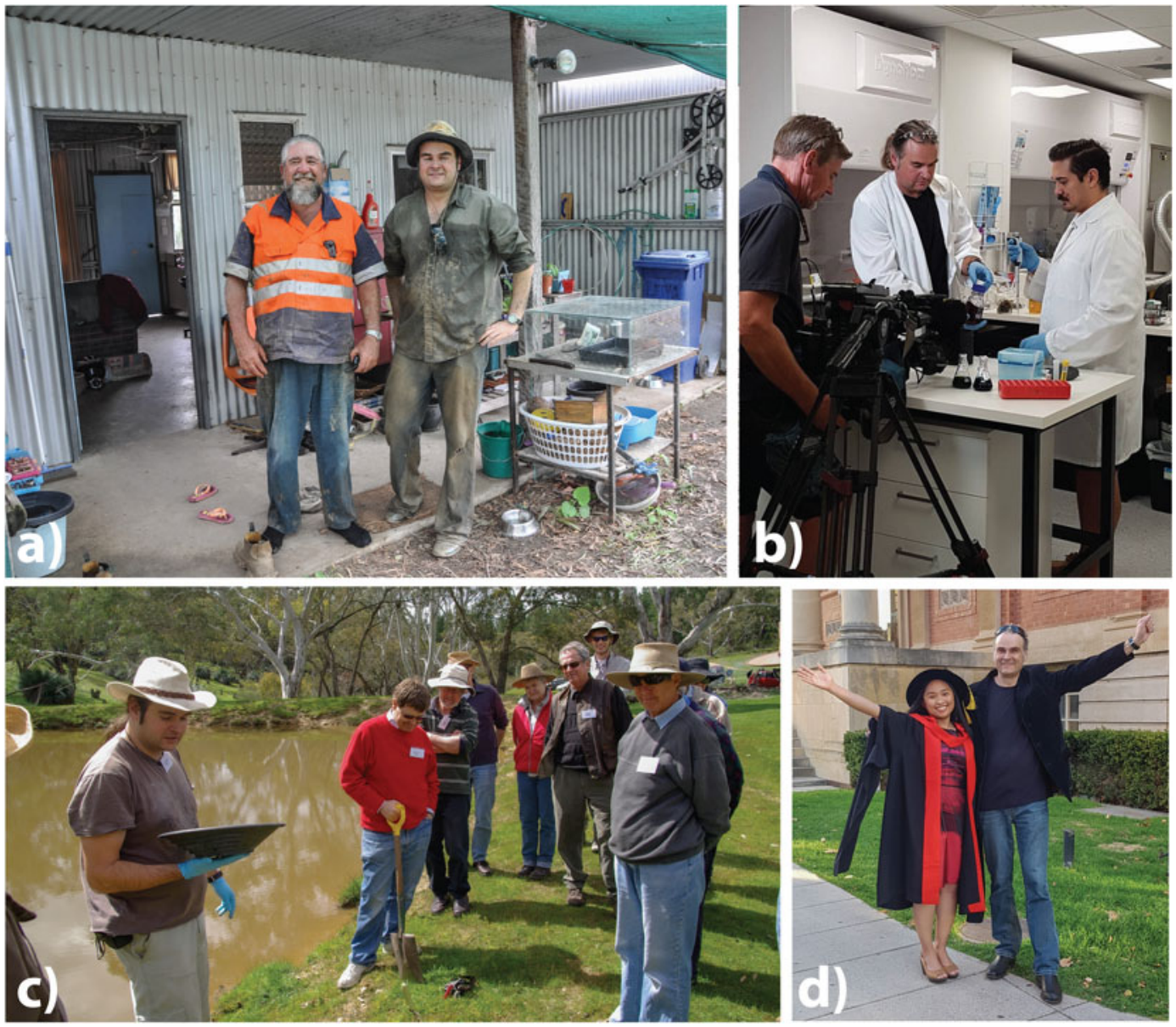

Fig. 7. Communicating science and mentoring. (a) Working closely with artisanal miners is the secret to getting access to exceptional gold samples and test sites. Frank and John Parsons from the Prophet Gold Mine in Kilkivan, Australia. (b) Interviewing together with Jeremiah Shuster for Scope TV (10play.com.au; 02/03/ 2018) at the Waite CSIRO laboratories. (c) Guiding a field trip to the Barossa gold fields for the Waterhouse Club, a support group of the South Australian Museum (15/9/2007). (d) Graduation ceremony of Dr Maria Angelica D. Rea (29/4/2019).

Broome, the Pilbara, Kalgoorlie, Perth and the Boddington gold mine, and back to Adelaide via the Nullarbor (Fig. 6a). Although not a golfer, Frank took great delight in playing the Nullarbor golf links, an 18-hole par 72 course that spans $1365 \mathrm{~km}$ on the Nullarbor plain. Aside from collecting numerous gold grains and associated samples (sediments and groundwaters), this trip produced $>100$ soil samples that contributed to the BASE project.

Frank's passion for science, his love of wine - and whiskey (Fig. 4) - and his engaging personality were key in opening doors with a variety of people from different backgrounds (Fig. 7). Through his adventures, he developed many strong friendships with local small-scale miners who appreciated his adaptability in the field. Through these friendships, Frank gained access to exciting and rare sampling locations - the ultimate adventurous journey of sharing what he found fascinating about the world around him.

\section{"All that is gold does not glitter, Not all those who wander are lost...." J.R.R. Tolkien}

One of Frank's long-time dreams was to retrace the tracks of North American gold-rush miners. As with any adventure, however, the path can take the traveller on a sudden and unexpected direction with no option to turn back. During a field excursion in
California, Frank's health declined rapidly and Frank and Tina were advised to return immediately to Adelaide. Frank was diagnosed with pancreatic cancer and underwent a series of major operations. With the tireless support of Tina, Frank received all

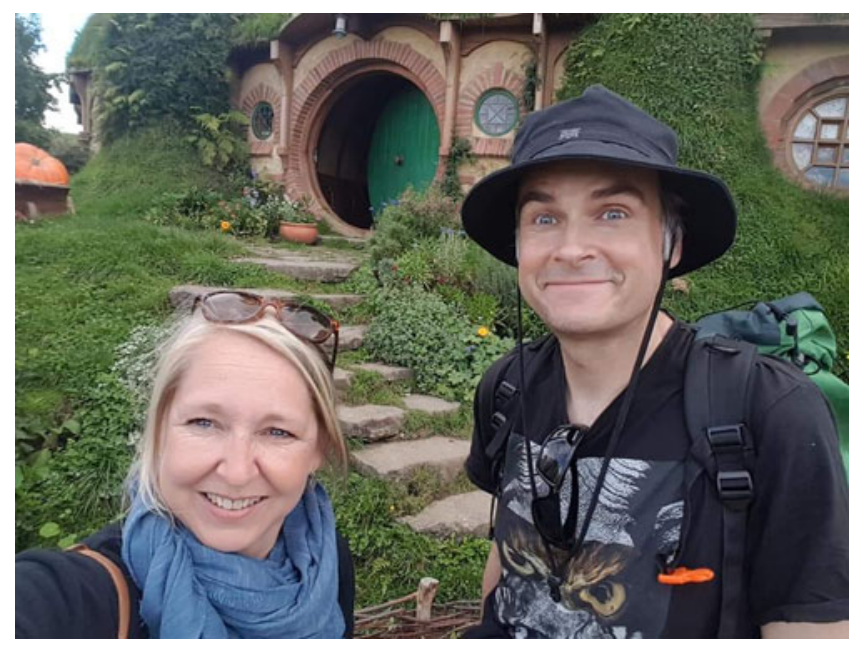

Fig. 8. Frank and Tina in Middle Earth, May 2019. 
possible treatment over the next 18 months in hopes to prolong his adventures - he wanted to continue a life well lived. In doing so, Frank shared scientific discoveries by assisting his graduate students to complete their research (e.g. Fig. 7d); he visited family in Germany and hosted many friends in Adelaide when physically possible; he delivered an emotional plenary presentation at the International Mineralogical Association (IMA) 2018 Conference in Melbourne (Mills and Missen, 2018) as well as an invited talk to commemorate the passing of his PhD mentor, 'Bear' McPhail; he made his last adventure to Middle Earth (New Zealand; Fig. 8). With his companion by his side and surrounded by the mementos of his adventures in their home base, Frank's life journey ended peacefully on the 14th of October 2019. Frank had a great gift in communicating the excitement and novelty of his research with people from all walks of life. His passion for sharing the joy of science, discovery, and his life lessons will be cherished in the memories of his wide circle of friends and colleagues.

Acknowledgements. The authors are grateful to Tina Reith for contributing images and information, and Alexander Pring, Barbara Eschmann and Angel Rea for their contributions to early drafts. This obituary also benefited from careful reviews by Janice P.L. Kenney and Stuart Mills.

\section{References}

Bissett A., Fitzgerald A., Meintjes T., Mele P.M., Reith F., Dennis P.G., Breed M.F., Brown B., Brown M.V., Brugger J., Byrne M., Caddy-Retalic S., Carmody B., Coates D.J., Correa C., Ferrari B.C., Gupta V.V.S.R., Hamonts K., Haslem A., Hugenholtz P., Karan M., Koval J., Lowe A.J., Macdonald S., McGrath L., Martin D., Morgan M., North K.I., Paungfoo-Lonhienne C., Pendall E., Phillips L., Pirzl R., Powell J.R., Ragan M.A., Schmidt S., Seymour N., Snape I., Stephen J.R., Stevens M., Tinning M., Williams K., Yeoh Y.K., Zammit C.M. and Young A. (2016) Introducing BASE: The biomes of Australian soil environments soil microbial diversity database. Gigascience, 5, 21, $11 \mathrm{pp}$.

Fairbrother L., Etschmann B., Brugger J., Shapter J., Southam G. and Reith F. (2013) Biomineralization of gold in biofilms of Cupriavidus metallidurans. Environmental Science \& Technology, 47, 2628-2635.

Mills S.J. and Missen O.P. (2018) IMA2018 memories. Elements, 14(6), 435 [http://www.elementsmagazine.org/archives/e14_6/e14_6_dep_meetingreport.pdf].

Reith F., Brugger J., Zammit C.M., Gregg A.L., Goldfarb K.C., Andersen G.L., DeSantis T.Z., Piceno Y.M., Brodie E.L., Lu Z., He Z., Zhou J. and Wakelin S.A. (2012a) Influence of geogenic factors on microbial communities in metallogenic Australian soils. ISME Journal, 6, 2107-2118.

Reith F., Stewart L. and Wakelin S.A. (2012b) Supergene gold transformation: Secondary and nano-particulate gold from southern New Zealand. Chemical Geology, 320, 32-45.

Reith F., Brugger J., Zammit C.M., Nies D.H. and Southam G. (2013) Geobiological cycling of gold: From fundamental process understanding to exploration solutions. Minerals, 3, 367-394.

Reith F., Campbell S.G., Ball A.S., Pring A. and Southam G. (2014) Platinum in Earth surface environments. Earth-Science Reviews, 131, 1-21.

Reith F., Nolze G., Saliwan-Neumann R., Etschmann B., Kilburn M.R. and Brugger J. (2019) Unravelling the formation histories of placer gold and platinum-group mineral particles from Corrego Bom Successo, Brazil: A window into noble metal cycling. Gondwana Research, 76, 246-259.

Sanyal S.K., Shuster J., Delport J., Dixon R., Etschmann B., Brugger J., Pedersen S.M. \& Reith F. (2020) Heavy-metal contamination affects the gold biogeochemical cycling. Science of the Total Environment, 727, 138698, 14 pp.

Ta C., Reith F., Brugger J., Pring A. and Lenehan C.E. (2014) Analysis of gold (I/III)-complexes by HPLC-ICP-MS demonstrates gold(III) stability in surface waters. Environmental Science \& Technology, 48, 5737-5744.

\section{Appendix - list of publications in chronological order}

Araujo R., Gupta V.V.S.R., Reith F., Bissett A., Mele P. and Franco C.M.M. (2020) Biogeography and emerging significance of actinobacteria in Australia and Northern Antarctica soils. Soil Biology and Biochemistry, 146, 107805, 9 pp.

Crede L.S., Evans K.A., Rempel K.U., Brugger J., Etschmann B., Bourdet J. and Reith F. (2020) Revisiting hydrocarbon phase mobilization of $\mathrm{Au}$ in the Au-Hg McLaughlin Mine, Geysers/Clear Lake area, California. Ore Geology Reviews, 117, 103218.

Missen O.P., Ram R., Mills S.J., Etschmann B., Reith F., Shuster J., Smith D. J. and Brugger J. (2020) Love is in the Earth: a review of tellurium (bio)geochemistry in surface environments. Earth Science Reviews, 204, 103150, $30 \mathrm{pp}$.

Reith F., Falconer D.M., Van Nostrand J., Craw D., Shuster J. and Wakelin S. (2020) Functional capabilities of bacterial biofilms on gold particles. FEMS Microbiology Ecology, 96, fiz196, 15 pp.

Shar S.S., Reith F., Shahsavari E., Adetutu E.M., Nurulita Y., Al-Hothaly K., Haleyur N. and Ball A.S. (2019) Biomineralization of platinum by Escherichia coli. Metals, 9, 407, 8 pp.

Sanyal S.K., Shuster J. and Reith F. (2019) Cycling of biogenic elements drives biogeochemical gold cycling. Earth-Science Reviews, 190, 131-147.

Sanyal S.K., Shuster J. and Reith F. (2019) Biogeochemical gold cycling selects metal-resistant bacteria that promote gold particle transformation. FEMS Microbiology Ecology, 95, fiz078, 16 pp.

Reith F., Verboom W., Pate J. and Chittleborough D. (2019b) Collaborative involvement of woody plant roots and rhizosphere microorganisms in the formation of pedogenetic clays. Annals of Botany, 124, 1007-1018.

Rea M.A.D., Wulser P.A., Brugger J., Etschmann B., Bissett A., Shuster J. and Reith F. (2019) Effect of physical and biogeochemical factors on placer gold transformation in mountainous landscapes of Switzerland. Gondwana Research, 66, 77-92.

Rea M.A., Shuster J., Hoffmann V.E., Schade M., Bissett A. and Reith F. (2019) Does the primary deposit affect the biogeochemical transformation of placer gold and associated biofilms? Gondwana Research, 73, 77-95.

Shuster J. and Reith F. (2018) Reflecting on gold geomicrobiology research: Thoughts and considerations for future endeavors. Minerals, 8, 401, $12 \mathrm{pp}$.

Shuster J., Rea M.A., Etschmann B., Brugger J. and Reith F. (2018) Terraced iron formations: Biogeochemical processes contributing to microbial biomineralization and microfossil preservation. Geosciences, 8, 480, 20 pp.

Rickels W., Reith F., Keller D., Oschlies A. and Quaas M.F. (2018) Integrated assessment of carbon dioxide removal. Earths Future, 6, 565-582.

Reith F. and Shuster J. (2018) Editorial for special issue "Geomicrobiology and biogeochemistry of precious metals". Minerals, 8.

Reith F., Rea M.A.D., Sawley P., Zammit C.M., Nolze G., Reith T., Rantanen K. and Bissett A. (2018) Biogeochemical cycling of gold: Transforming gold particles from arctic Finland. Chemical Geology, 483, 511-529.

Rea M.A., Standish C.D., Shuster J., Bissett A. and Reith F. (2018) Progressive biogeochemical transformation of placer gold particles drives compositional changes in associated biofilm communities. FEMS Microbiology Ecology, 94, fiy080, $15 \mathrm{pp}$.

Melchiorre E.B., Orwin P.M., Reith F., Rea M.A.D., Yahn J. and Allison R. (2018) Biological and geochemical development of placer gold deposits at Rich Hill, Arizona, USA. Minerals, 8, 56, 20 pp.

Delgado-Baquerizo M., Reith F., Dennis P.G., Hamonts K., Powell J.R., Young A., Singh B.K. and Bissett A. (2018) Ecological drivers of soil microbial diversity and soil biological networks in the southern hemisphere. Ecology, 99, 583-596.

Campbell G., MacLean L., Reith F., Brewe D., Gordon R.A. and Southam G. (2018) Immobilisation of platinum by Cupriavidus metallidurans. Minerals, 8, 10, 18 pp.

Butof L., Wiesemann N., Herzberg M., Altzschner M., Holleitner A., Reith F. and Nies D.H. (2018) Synergistic gold-copper detoxification at the core of gold biomineralisation in Cupriavidus metallidurans. Metallomics, 10, 278286.

Wiesemann N., Butof L., Herzberg M., Hause G., Berthold L., Etschmann B., Brugger J., Martinez-Criado G., Dobritzsch D., Baginsky S., Reith F. and Nies D.H. (2017) Synergistic toxicity of copper and gold compounds in 
Cupriavidus metallidurans. Applied and Environmental Microbiology, 83, e01679, 17 pp.

Shuster J., Reith F., Izawa M.R.M., Flemming R.L., Banerjee N.R. and Southam G. (2017) Biogeochemical cycling of silver in acidic, weathering environments. Minerals, 7, 218, 18 pp.

Shuster J., Reith F., Cornelis G., Parsons J.E., Parsons J.M. and Southam G. (2017) Secondary gold structures: Relics of past biogeochemical transformations and implications for colloidal gold dispersion in subtropical environments. Chemical Geology, 450, 154-164.

Reith F. and Cornelis G. (2017) Effect of soil properties on gold- and platinum nanoparticle mobility. Chemical Geology, 466, 446-453.

Kerr G., Falconer D., Reith F. and Craw D. (2017) Transport-related mylonitic ductile deformation and shape change of alluvial gold, southern New Zealand. Sedimentary Geology, 361, 52-63.

Etschmann B., Liu W.H., Li K., Dai S.F., Reith F., Falconer D., Kerr G., Paterson D., Howard D., Kappen P., Wykes J. and Brugger J. (2017) Enrichment of germanium and associated arsenic and tungsten in coal and roll-front uranium deposits. Chemical Geology, 463, 29-49.

Delgado-Baquerizo M., Powell J.R., Hamonts K., Reith F., Mele P., Brown M.V., Dennis P.G., Ferrari B.C., Fitzgerald A., Young A., Singh B.K. and Bissett A. (2017) Circular linkages between soil biodiversity, fertility and plant productivity are limited to topsoil at the continental scale. New Phytologist, 215, 1186-1196.

Zammit C.M., Weiland F., Brugger J., Wade B., Winderbaum L.J., Nies D.H., Southam G., Hoffmann P. and Reith F. (2016) Proteomic responses to gold (III)-toxicity in the bacterium Cupriavidus metallidurans CH34. Metallomics, 8, 1204-1216.

Reith F., Zammit C.M., Shar S.S., Etschmann B., Bottrill R., Southam G., Ta C., Kilburn M., Oberthuer T., Ball A.S. and Brugger J. (2016) Biological role in the transformation of platinum-group mineral grains. Nature Geoscience, 9, 294-298.

Rea M.A., Zammit C.M. and Reith F. (2016) Bacterial biofilms on gold grains-implications for geomicrobial transformations of gold. FEMS Microbiology Ecology, 92, fiw082, 12 pp.

Li K., Etschmann B., Rae N., Reith F., Ryan C.G., Kirkham R., Howard D., Rosa D.R.N., Zammit C., Pring A., Ngothai Y., Hooker A. and Brugger J. (2016) Ore petrography using megapixel $x$-ray imaging: Rapid insights into element distribution and mobilization in complex Pt and $\mathrm{U}-\mathrm{Ge}-\mathrm{Cu}$ ores. Economic Geology, 111, 487-501.

Etschmann B., Brugger J., Fairbrother L., Grosse C., Nies D.H., MartinezCriado G. and Reith F. (2016) Applying the Midas touch: Differing toxicity of mobile gold and platinum complexes drives biomineralization in the bacterium Cupriavidus metallidurans. Chemical Geology, 438, 103-111.

Ta C., Brugger J., Pring A., Hocking R.K., Lenehan C.E. and Reith F. (2015) Effect of manganese oxide minerals and complexes on gold mobilization and speciation. Chemical Geology, 407, 10-20.

Reith F., Zammit C.M., Pohrib R., Gregg A.L. and Wakelin S.A. (2015) Geogenic factors as drivers of microbial community diversity in soils overlying polymetallic deposits. Applied and Environmental Microbiology, 81, $7822-7832$.

Craw D., Kerr G., Reith F. and Falconer D. (2015) Pleistocene paleodrainage and placer gold redistribution, Western Southland, New Zealand. New Zealand Journal of Geology and Geophysics, 58, 137-153.

Campbell S.G., Reith F., Etschmann B., Brugger J., Martinez-Criado G., Gordon R.A. and Southam G. (2015) Surface transformations of platinum grains from Fifield, New South Wales, Australia. American Mineralogist, 100, 1236-1243.

Zammit C.M., Brugger J., Southam G. and Reith F. (2014) In situ recovery of uranium - the microbial influence. Hydrometallurgy, 150, 236-244.

Weiland F., Zammit C.M., Reith F. and Hoffmann P. (2014) High resolution two-dimensional electrophoresis of native proteins. Electrophoresis, 35, 1893-1902.

Watling H.R., Collinson D.M., Li J., Mutch L.A., Perrot F.A., Rea S.M., Reith F. and Watkin E.L.J. (2014) Bioleaching of a low-grade copper ore, linking leach chemistry and microbiology. Minerals Engineering, 56, 35-44.

Zammit C.M., Quaranta D., Gibson S., Zaitouna A.J., Ta C., Brugger J., Lai R.Y., Grass G. and Reith F. (2013) A whole-cell biosensor for the detection of gold. PLOS One, 8, e69292, 8 pp.
Zammit C., Li K., Etschmann B., Brugger J. and Reith F. (2013) Geobiology of in situ uranium leaching. Pp. 372-375 in: Integration of Scientific and Industrial Knowledge on Biohydrometallurgy (N. Guiliani, C. Demergasso, R. Quatrini, F. Remonsellez, C. DavisBelmar, G. Levican, P. Parada, C. Barahona, and R. Zale, editors) Advanced Materials Research, 825.

Wiesemann N., Mohr J., Grosse C., Herzberg M., Hause G., Reith F. and Nies D.H. (2013) Influence of copper resistance determinants on gold transformation by Cupriavidus metallidurans strain CH34. Journal of Bacteriology, 195, 2298-2308.

Brugger J., Etschmann B., Grosse C., Plumridge C., Kaminski J., Paterson D., Shar S.S., Ta C., Howard D.L., de Jonge M.D., Ball A.S. and Reith F. (2013) Can biological toxicity drive the contrasting behavior of platinum and gold in surface environments? Chemical Geology, 343, 99-110.

Zammit C.M., Cook N., Brugger J., Ciobanu C.L. and Reith F. (2012) The future of biotechnology for gold exploration and processing. Minerals Engineering, 32, 45-53.

Wakelin S.A., Anand R.R., Reith F., Gregg A.L., Noble R.R.P., Goldfarb K.C., Andersen G.L., DeSantis T.Z., Piceno Y.M. and Brodie E.L. (2012) Bacterial communities associated with a mineral weathering profile at a sulphidic mine tailings dump in arid western Australia. FEMS Microbiology Ecology, 79, 298-311.

Wakelin S., Anand R.R., Macfarlane C., Reith F., Noble R. and Rogers S. (2012) Assessing microbiological surface expression over an overburden-covered VMS deposit. Journal of Geochemical Exploration, 112, 262-271.

Reith F., Zammit C.M., Rogers S.L., McPhail D.C. and Brugger J. (2012c) Potential utilisation of micro-organisms in gold processing: A review. Transactions of the Institutions of Mining and Metallurgy Section C Mineral Processing and Extractive Metallurgy, 121, 251-260.

Fairbrother L., Brugger J., Shapter J., Laird J.S., Southam G. and Reith F. (2012) Supergene gold transformation: Biogenic secondary and nano-particulate gold from arid Australia. Chemical Geology, 320, 17-31.

Cabral A.R., Reith F., Lehmann B., Brugger J., Meinhold G., Tupinamba M. and Kwitko-Ribeiro R. (2012) Anatase nanoparticles on supergene platinum-palladium aggregates from brazil: Titanium mobility in natural waters. Chemical Geology, 334, 182-188.

Reith F., Etschmann B., Dart R.C., Brewe D.L., Vogt S., Mumm A.S. and Brugger J. (2011) Distribution and speciation of gold in biogenic and abiogenic calcium carbonates - implications for the formation of gold anomalous calcrete. Geochimica et Cosmochimica Acta, 75, 1942-1956.

Reith F. (2011) Life in the deep subsurface. Geology, 39, 287-288.

Reith F., Fairbrother L., Nolze G., Wilhelmi O., Clode P., Gregg A., Parsons J., Wakelin S., Pring A., Hough R., Southam G. and Brugger J. (2010) Nanoparticle factories: Biofilms hold the key to gold dispersion and nugget formation. Geology, 38, 843-846.

Phillips G., Reith F., Qualls C., Ali A.M., Spilde M. and Appenzeller O. (2010) Bacterial deposition of gold on hair: Archeological, forensic and toxicological implications. PLOS One, 5, e9335, 7 pp.

Brugger J., Pring A., Reith F., Ryan C., Etschmann B., Liu W., O’Neill B. and Ngothai Y. (2010) Probing ore deposits formation: New insights and challenges from synchrotron and neutron studies. Radiation Physics and Chemistry, 79, 151-161.

Southam G., Lengke M.F., Fairbrother L. and Reith F. (2009) The biogeochemistry of gold. Elements, 5, 303-307.

Reith F., Wakelin S.A., Gregg A.L. and Schmidt Mumm A. (2009) A microbial pathway for the formation of gold anomalous calcrete. Chemical Geology, 258, 315-326.

Reith F., Etschmann B., Grosse C., Moors H., Benotmane M., Monsieurs P., Grass G., Doonan C., Vogt S., Lai B., Martinez-Criado G., George G., Nies D., Mergeay M., Pring A., Southam G. and Brugger J. (2009) Mechanisms of gold biomineralization in the bacterium Cupriavidus metallidurans. Proceedings of the National Academy of Sciences of the United States of America, 106, 17757-17762.

Reith F. and Rogers S.L. (2008) Assessment of bacterial communities in auriferous and non-auriferous soils using genetic and functional fingerprinting. Geomicrobiology Journal, 25, 203-215.

Reith F., Dürr M., Welch S. and Rogers S.L. (2008) The geomicrobiology of the regolith. Pp. 127-159 in: Regolith Science (K. Scott and C.F. Pain, editors). CSIRO Press, Melbourne, Australia. 
Reith F., Rogers S., McPhail D. and Brugger J. (2007) Potential for the utilisation of micro-organisms in gold processing. Pp. 67-74 in: World Gold 2007 (ISBN: 9781920806743).

Reith F. and McPhail D.C. (2007) Mobility and microbially mediated mobilization of gold and arsenic in soils from two gold mines in semi-arid and tropical Australia. Geochimica et Cosmochimica Acta, 71, 1183-1196.

Reith F., Lenke M.F., Falconner D., Craw D. and Southam G. (2007) Winogradski review - the geomicrobiology of gold. The ISME Journal, $\mathbf{1}$, 567-584.

Mumm A.S. and Reith F. (2007) Biomediation of calcrete at the gold anomaly of the Barns prospect, Gawler craton, South Australia. Journal of Geochemical Exploration, 92, 13-33.
Reith F., Rogers S.L., McPhail D.C. and Webb D. (2006) Biomineralization of gold: Biofilms on bacterioform gold. Science, 313, 233-236.

Reith F. and McPhail D.C. (2006) Effect of resident microbiota on the solubilization of gold in soil from the Tomakin Park gold mine, New South Wales, Australia. Geochimica et Cosmochimica Acta, 70, 1421-1438.

Reith F., McPhail D.C. and Christy A.G. (2005) Bacillus cereus, gold and associated elements in soil and other regolith samples from Tomakin Park gold mine in southeastern New South Wales, Australia. Journal of Geochemical Exploration, 85, 81-98.

Reith F., Drake H.L. and Kusel K. (2002) Anaerobic activities of bacteria and fungi in moderately acidic conifer and deciduous leaf litter. FEMS Microbiology Ecology, 41, 27-35. 